\title{
An integrated Raman and petrographic characterization of Italian mediaeval artifacts in pietra ollare (soapstone)
}

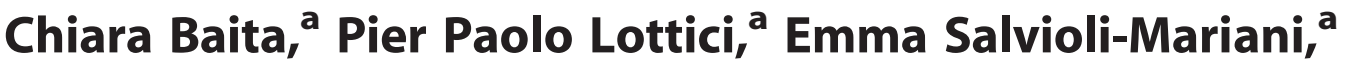 \\ Peter Vandenabeele, ${ }^{b}$ Mauro Librenti, ${ }^{c}$ Fabrizio Antonelli ${ }^{\mathrm{d}}$ \\ and Danilo Bersani ${ }^{\mathrm{a} *}$
}

\begin{abstract}
Ten fragments of pots made by pietra ollare (basic and ultrabasic metamorphic rocks belonging to greenschist facies) found in the archaeological site of Crocetta di Sant'Agata Bolognese (Bologna, Italy) have been studied to characterize them and to define their provenance. The fragments, dated between the $9^{\text {th }}$ and $10^{\text {th }}$ century AD, show traces of blackening from fire, indicating the use of these findings as pots by fire. The extensive use of a non-destructive technique, Raman spectroscopy, in both laboratory and portable forms, for the provenance analysis of pietra ollare artifacts has been evaluated. MicroRaman spectroscopy was used for a detailed study of the main components, to identify the secondary minerals and to study the distribution of the mineral phases in the samples. The samples show schistose texture, are fine grained and consist mainly of talc and chlorite, and subordinate carbonates, oxides and serpentine. Olivine is rare. Based on the mineralogical composition, the material can be defined as chlorite and carbonate talc-schist. Our samples of pietra ollare may be assigned to chlorite and magnesite-bearing talc-schists. The alpine areas of origin of this lithotype are Valtellina, Valchiavenna and Val Bregaglia. In particular, we can hypothesize that the origin of these findings is Valchiavenna, which had great commercial importance in the Middle Ages. Further measurements, obtained with a portable Raman spectrometer, directly on a quarry near Chiavenna, support our hypothesis. Copyright $\odot 2013$ John Wiley \& Sons, Ltd.
\end{abstract}

Keywords: micro-Raman spectroscopy; mobile Raman spectroscopy; in situ analysis; pietra ollare; archaeometry

\section{Introduction}

The Italian term pietra ollare (sometimes translated in English as 'soapstone') hasn't a specific petrological meaning. Usually it refers to a metamorphic rock constituted prevalently by talc, magnesite and dolomite including chlorite, amphibole, mica, epidote and albite as accessory minerals. In the archaeological field, this term is used to denote different lithotypes with distinct composition, colour and aspect, but having many physical and chemical characteristics in common. They are mostly composed of silicates with high chemical resistance to weathering and also to food cooking. They have good thermal stability up to very high temperature (generally $>1000{ }^{\circ} \mathrm{C}$ ) before sintering and they are resistant to fast temperature changes assuring a regular linear expansion. ${ }^{[1]}$ Pietra ollare shows very low porosity despite its schistose texture (total porosity is generally $\leq 1-3 \%$, as a function of the more or less marked schistosity $\left.{ }^{[1]}\right)$. Their principal minerals have very low hardness (up to 4 in the Mohs scale); ${ }^{[2]}$ they could therefore be easily processed with metallic instruments both by hand and lathe. Common lithotypes of pietra ollare are represented by grey to pale-green, medium- to fine-grained rocks containing predominantly talc, chlorite and carbonates, but they can be more correctly classified in four main groups: chlorite-schist, talc-schist (sometimes amphibole-bearing talc-schists \pm carbonates), serpentineschists and ultrabasites.

In all cases, they are rocks that have been transformed in the frame of the Alpine polyphasic metamorphic evolution and so they are located along the metamorphic axes of the Alps; these rocks outcrop from the Sestri-Ponente-Voltaggio line near Genoa to the Stiria. Due to its interesting physical-thermal features, the pietra ollare lithotypes were largely used between the Late Roman Empire and the Middle Ages, when the trade network swiftly expanded becoming clearly extra-regional.

The present investigation is carried out on ten fragments of pots made from pietra ollare, dated between $9^{\text {th }}$ and $10^{\text {th }}$ century $A D$, found in the archaeological site of Crocetta di Sant'Agata Bolognese (Bologna, Italy). ${ }^{[3]}$ The main scope of this study is to define their geological-geographic provenance mainly by Raman measurements.

\footnotetext{
* Correspondence to: Danilo Bersani, Physics and Earth Sciences, University of Parma, Parco Area delle Scienze 7/A, 43124 Parma, Italy. E-mail: danilo. bersani@fis.unipr.it

a Dipartimento di Fisica e Scienze della Terra, Università di Parma, Parco Area delle Scienze 7/A, 43124 Parma, Italy

b Ghent University, Department of Archaeology, Archaeometry Research Group, Sint-Pietesnieuwstraat 35, B-9000 Ghent, Belgium

c Dipartimento di Scienze dell' Antichità e del Vicino Oriente, Università Ca Foscari, Dorsoduro 3484/d, 30123 Venezia, Italy

d Dipartimento di Architettura Costruzione Conservazione, Università IUAV di Venezia, Badoer, San Polo 2468B, 30125 Venezia
} 
Examples of provenance studies on pietra ollare pots and millstones are already present in literature. ${ }^{[4-8]}$ They are usually based on standard petrological techniques as thin sections, X-ray diffraction (XRD) and scanning electron microscopy coupled with energy-dispersive X-ray spectroscopy (SEM-EDX). Here, we want to evaluate the potential of Raman spectroscopy in provenance studies, as a first step to establish a completely non-destructive way to characterize this kind of artifact. In particular, we test the combination between the laboratory study of the archaeological findings and the in situ study, with portable Raman equipment, directly on rocks in a Valchiavenna quarry. In recent years, the use of mobile and portable Raman systems is increasing for the analysis of archaeological and artistic objects and in situ identification of minerals. ${ }^{[9-13]}$ Nevertheless, to the authors' knowledge, no works have been published on the Raman study of archaeological findings in pietra ollare, despite its very large diffusion.

\section{Experimental}

The ten fragments investigated were all found in the archaeological site of Crocetta di Sant'Agata Bolognese (Bologna, Italia), a walled Middle Age village, located near a riverway. From archaeological evidences, ${ }^{[3]}$ in particular from the stratigraphy of the site, the fragments made from pietra ollare are dated between $9^{\text {th }}$ and $10^{\text {th }}$ century AD. They are fragments of cylindrical pots, each with maximum dimension of about 5-15 cm, gray coloured, and show traces of lathe manufacturing. Some fragments are also characterized by a surface layer of blackening from fire, which confirms the use of these findings as pots by fire (Fig. 1). Thin sections from all the studied samples were obtained for petrographical analysis performed with a petrographic microscope equipped with polarizing system.

Subsequently, as the comparison of our data with literature $^{[5,6]}$ suggested Valchiavenna as the most probable source for the raw materials, the rocks present in a quarry located at Piuro, very close to the town of Chiavenna, have been analyzed in situ using a portable Raman spectrometer. The quarry inspected is still active, but it was re-opened on a historical quarrysite.
Powder X-ray diffraction was performed using a PANalytical EMPYREAN diffractometer with Ni-filtered CuK $\alpha$ radiation at 40 $\mathrm{kV}$ and $20 \mathrm{~mA}$ with a detection limit 3\%.

Non-polarized micro-Raman spectra were obtained on the raw samples and, for confirmation, on the thin sections, in nearly backscattered geometry, with a Jobin-Yvon Horiba 'Labram' apparatus, equipped with an Olympus microscope with $\times 10, \times 50$ and $\times 100$ objectives and a micrometric motorized $x-y$ stage for Raman mapping. The $632.8 \mathrm{~nm}$ line of a He-Ne laser and the $473.1 \mathrm{~nm}$ line of a doubled diode-pumped Nd:YAG laser were used as excitation; laser power was controlled by means of a series of density filters, in order to avoid heating effects. The minimum lateral resolution was set to about $1 \mu \mathrm{m}$ (using the $100 \times$ objective) by means of a confocal hole. The system was calibrated using the $520.6 \mathrm{~cm}^{-1}$ Raman band of silicon before each experimental session. The spectral resolution is $3 \mathrm{~cm}^{-1}$ when using the $632.8 \mathrm{~nm}$ laser line.

SEM-EDX analysis was performed with a Jeol 6400 scanning electron microscope equipped with Oxford (Link) EDX microanalysis (15 kV, $0.28 \mathrm{nA}, \sim 1 \mu \mathrm{m}$ beam diameter, $60 \mathrm{~s}$ counting time). Elemental data were then obtained using the Oxford INCAEnergy software.

Raman spectra of minerals in the field were recorded by using an Enwave Optronics EZRaman-I-Dual-G Raman spectrometer. This mobile instrument is equipped with two lasers $(785 \mathrm{~nm}$ and 532 $\mathrm{nm}$ ) and is battery powered, with many hours of battery life. An external battery pack can provide up to $10 \mathrm{~h}$ of operation. This system is equipped with two fibre-optics probeheads. Both fibres are $5 \mathrm{~m}$ long. Probeheads were manually positioned and a copper tube was slid over the lens tube ${ }^{[14]}$ to shield the measurement spot from sunlight (Fig. 2). Spectra are recorded in the range $100-2200 \mathrm{~cm}^{-1}$ for $785 \mathrm{~nm}$ laser and $100-3100 \mathrm{~cm}^{-1}$ for $532 \mathrm{~nm}$ laser. The built-in small laptop contains all operating software and allows to store all spectra in the standard .spc file format. The whole system is mounted in a rigid case and weighs ca. $17 \mathrm{~kg}$.

\section{Results}

\section{Petrography}

According to their petrographic features, the fragments from Crocetta di Sant'Agata Bolognese can be divided into three types,

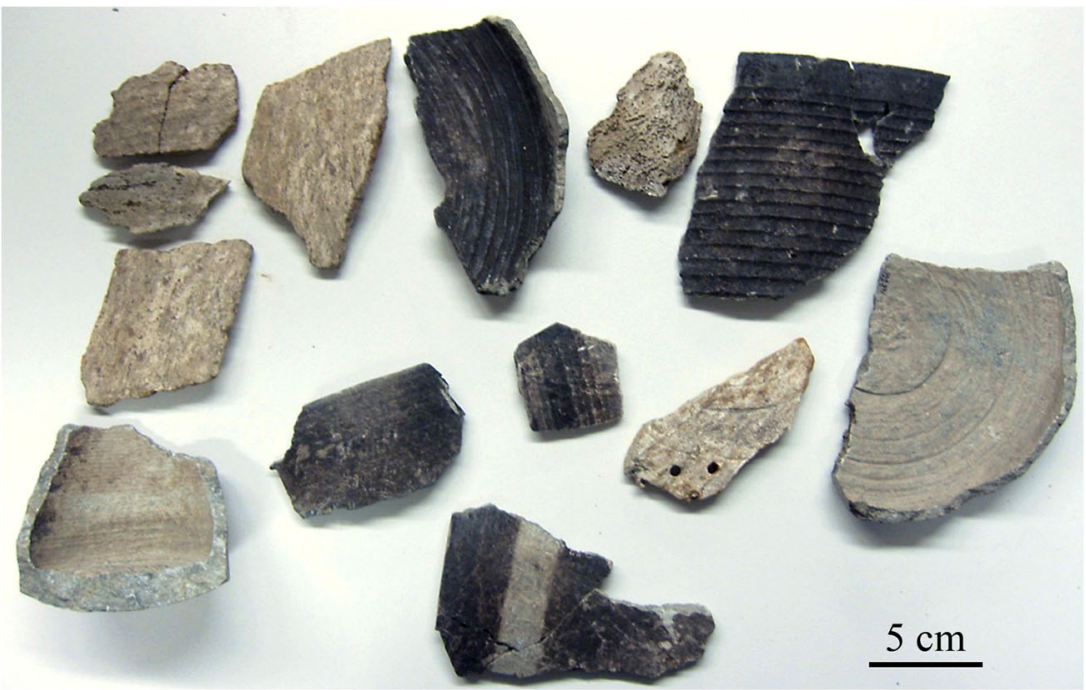

Figure 1. The fragments of pots made by pietra ollare found in archaeological site of Crocetta di Sant'Agata Bolognese (Bologna, Italy). 


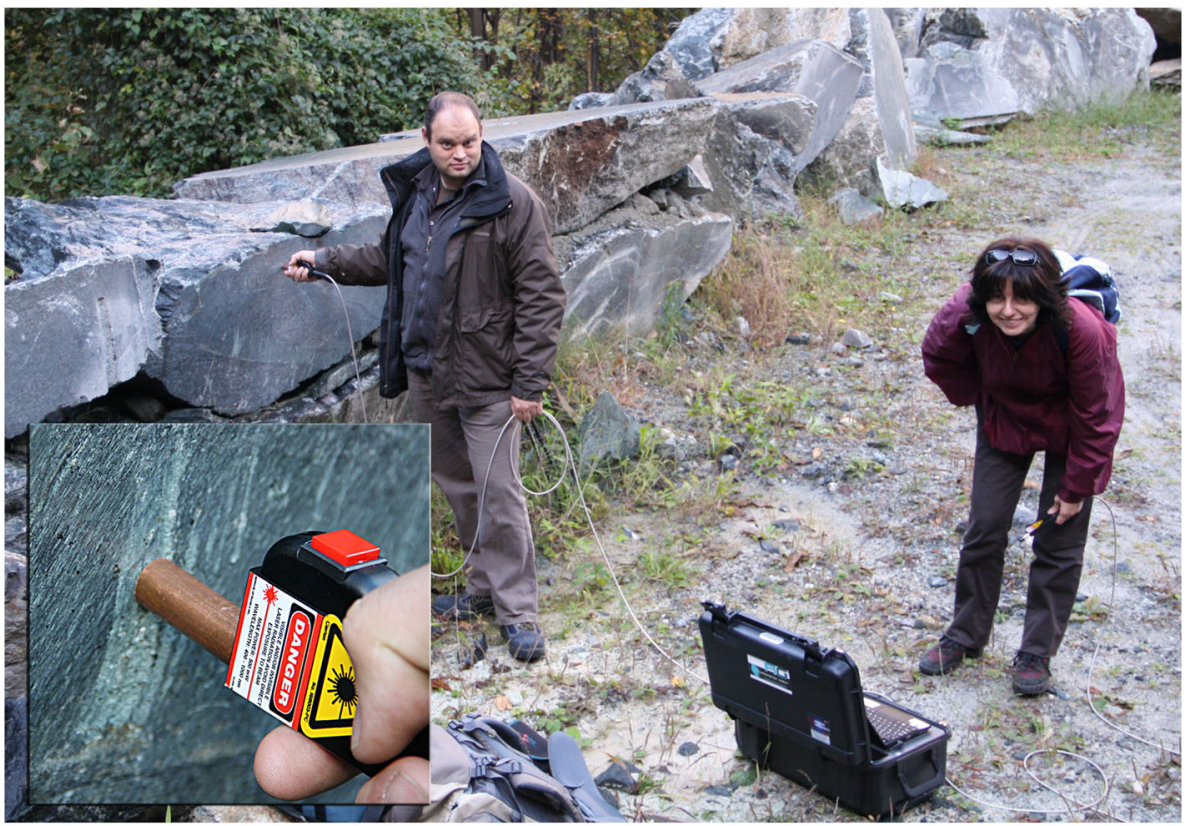

Figure 2. The portable Raman apparatus used in the Piuro quarry in Valchiavenna (Italy). In the inset, a detail of the probehead with the copper tube acting as a spacer and a light shield.

with small variations within each one: (1) carbonate (magnesite)bearing talc-schists, (2) pure talc-schists, (3) talc-carbonate (magnesite and dolomite)-bearing chlorite-schists. Sample \#9 can be considered an isolated case.

The talc-schists of the first group have a texture which varies from schistosity with more or less well-developed microfolds $(\# 1, \# 2, \# 3)$ (Fig. 3A, B) to a very deformed texture without any preferred orientation (\#4, \#5) (Fig. 3C). Talc and magnesium carbonate (magnesite, rare dolomite only in \#4) are the main minerals, with variable relative abundance among the samples. Talc occurs as slightly coloured or colourless flakes, with variable size. The flakes are sometimes arranged to define a good foliation even if some small deformation as microfolds occurs (Fig. 3B), sometimes without any preferential orientation giving to the rock a highly disordered texture (Fig. 3C). Larger lamellas cut the schistosity and thus they are subsequent to the foliation-forming deformation. Small crystals of magnesite are often idiomorphic, with rhombohedral shape (Fig.3D); they are grown up along the foliation and help to describe the microfolds (Fig. 3B), suggesting recrystallization contemporaneously to the deformation. The larger crystals are pecilitic and contain small laminas of talc which are inflected in continuity with the rock foliation suggesting crystal growth during the formation of the foliation (Fig. 3E). Chlorite is rare or absent, it is slightly coloured and forms small fibrous-radial aggregates; rarely flakes of chlorite are associated with talc. In the sample \#3, rarely serpentine occurs, associated with talc.

The talc-schists of the second group have an extremely regular schistose texture (Fig. 3F), without any successive deformation (\#6, \#7). Talc is the main mineral, as colourless or slightly coloured flakes. Abundant opaque minerals occur, above all in the sample \#6; they are placed in some areas associated with rare chlorite, colourless larger laminas of talc, discordant with respect to the foliation, and serpentine. These aggregates constituted by talc + opaque minerals + chlorite \pm serpentine (\#6) or by serpentine + talc + opaque minerals (\#7) are probably the product of the transformation of olivine (Fig. 3F).
The fragments belonging to the third group are characterized by a schistose texture with microfolds defined by flakes of chlorite (\#8). Colourless chlorite is the main mineral; thus, the rock can be defined as chlorite-schist (Fig. 3G). Small laminas of talc also occur and they are associated to chlorite to form the bulk foliation, whereas larger laminas cut the foliation (Fig. 3H). Small crystals of magnesite, very rarely dolomite, form aggregates often discordant with the foliation. Some of them contain small laminas of talc which show an orientation completely different from bulk foliation; this suggests crystal growth after formation of schistosity (Fig. 3I).

The isolated sample (\#9) is formed by talc in large laths associated to form a cluster, without any preferential orientation (Fig. 3L). Chlorite is subordinate but closely associated with talc and with the same features. Opaque minerals are abundant and are associated with red-orange coloured material, difficult to identify. In these areas, rare calcite and serpentine also occur and they are probably the product of transformation of olivine and pyroxene. The results are summarized in Table 1

\section{Micro-Raman spectroscopy}

Raman analysis shows that the main component of the fragments is talc $\mathrm{Mg}_{3} \mathrm{Si}_{4} \mathrm{O}_{10}(\mathrm{OH})_{2}$, identified by the main band at $676 \mathrm{~cm}^{-1}$, attributed to the $\mathrm{Si}-\mathrm{O}_{\mathrm{b}}-\mathrm{Si}$ vibration $\left(\mathrm{O}_{\mathrm{b}}=\right.$ bridging oxygen $) .{ }^{[15]}$ Other Raman bands of talc are at $1052 \mathrm{~cm}^{-1}$, due to the $\mathrm{Si}-\mathrm{O}_{\mathrm{nb}}$ stretching $\left(\mathrm{O}_{\mathrm{nb}}=\right.$ non-bridging oxygen), at $195 \mathrm{~cm}^{-1}$ and $363 \mathrm{~cm}^{-1}$ (Fig. 4). The Raman band positions of the mineral phases found in our samples are summarized in Table 2.

The second phase, in terms of abundance, in some fragments, is a member of the chlorite group (Fig. 4). It is distinguishable from talc thanks to the band at $547 \mathrm{~cm}^{-1}$, typical of Fe-bearing phyllosilicates. ${ }^{[15]}$ The other bands are at $199 \mathrm{~cm}^{-1}$, typical of many trioctahedral phyllosilicates, at $354 \mathrm{~cm}^{-1}$, common for most Mg bearing phyllosilicates and a band at $679 \mathrm{~cm}^{-1}\left(\mathrm{Si}-\mathrm{O}_{\mathrm{b}}-\mathrm{Si}\right.$ vibration). From the Raman spectra, it is difficult to determine the exact member of the chlorite family present in our samples. We can make use of micro-Raman mapping ${ }^{[16]}$ to study the chlorite lamellae orientation. 

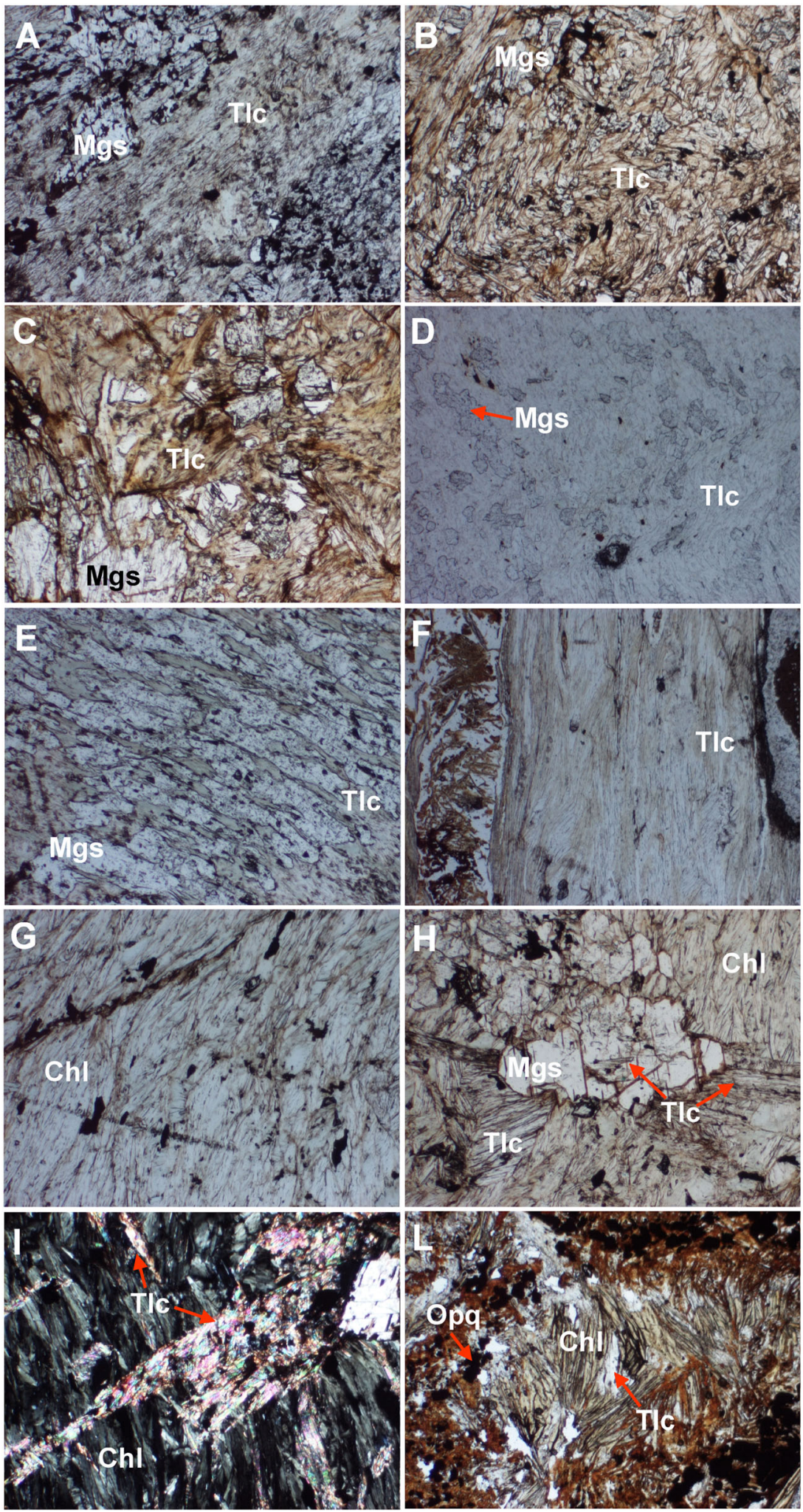

Figure 3. Transmitted light microphotographs of the studied fragments of pietra ollare. A-E, talc-schist of the first group showing schistosity (A) locally with well-defined microfolds (B) or texture without any preferential orientation (C); magnesite (Mgs) occurs in crystals of different sizes grown up contemporaneously with talc (Tlc) during the foliation-forming event (D,E). F, talc-schists of the second group with a regular schistosity and zones (on the left) with different mineral associations, products of transformation of olivine. G-I chlorite-schists with talc and magnesite cutting the foliation $(\mathrm{H}, \mathrm{l})$ defined by chlorite $(\mathrm{Chl})(\mathrm{G})$. L, isolated sample with association of opaque minerals (Opq) and red-orange undefined minerals (transformed olivine). Image size: $1.6 \mathrm{~mm} \times 2.1 \mathrm{~mm}$. 
Table 1. Results of the petrological analysis on the archaeological samples: Tlc, talc; Mgs, magnesite; Chl, chlorite; Do, dolomite; Cc, calcite; Srp, serpentine; Opq, opaque minerals

Sample Mineral paragenesis $\quad$ Texture Rock type

Talc-schist of the first group

$\begin{array}{lll}\# 1 & \mathrm{Tl} c+\mathrm{Mgs}+\mathrm{Opq} \pm \mathrm{Chl} & \text { schistosity more or less deformed } \\ \# 2 & \mathrm{Tlc}+\mathrm{Mgs}+\mathrm{Opq} \pm \mathrm{Chl} & \text { schistosity more or less deformed } \\ \# 3 & \mathrm{Mgs}+\mathrm{Tl}+\mathrm{Srp} \pm \mathrm{Opq} & \text { deformed schistosity } \\ \# 4 & \mathrm{Mgs}+\mathrm{Tl} c+\mathrm{Chl}+\mathrm{Opq} \pm \mathrm{Do} \pm \mathrm{Srp} & \text { very deformed without preferred orientation } \\ \# 5 & M g s+\mathrm{Tl}+\mathrm{Opq} \pm \mathrm{Chl} & \text { very deformed without preferred orientation }\end{array}$

Talc-schist of the second group

\#6 $\quad \mathrm{Tlc}+\mathrm{Opq}+\mathrm{Chl} \pm$ Srp

$\mathrm{Tlc}+\mathrm{Opq}+\mathrm{Srp}$

Chlorite-schist (third group)

\#8 $\mathrm{Chl}+\mathrm{Tlc}+\mathrm{Opq}+\mathrm{Mgs} \pm \mathrm{Do}$

$\# 10 \quad \mathrm{Chl}+\mathrm{Tlc}+\mathrm{Opq}+\mathrm{Mgs} \pm \mathrm{Do}$

Isolated sample

\#9 $\quad \mathrm{Tlc}+\mathrm{Chl}+\mathrm{Opq} \pm \mathrm{Cc} \pm$ Srp well-developed schistosity

well-developed schistosity

deformed schistosity

deformed schistosity
Mgs-bearing talc-schist

Mgs-bearing talc-schist

Mgs-bearing talc-schist

Mgs-bearing talc-schist

Mgs-bearing talc-schist

Talc-schist

Talc-schist

Tlc-Mgs-bearing chlorite-schist

Tlc-Mgs-bearing chlorite-schist

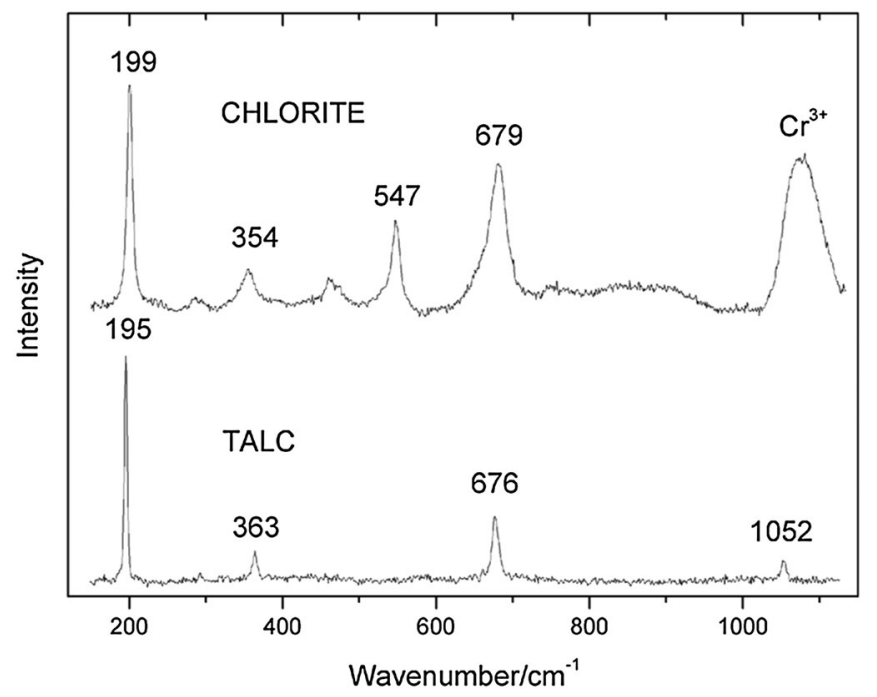

Figure 4. Micro-Raman spectra of chlorite and talc measured on the archaeological samples. A photoluminescence emission of $\mathrm{Cr}^{3+}$ ions is visible in the Raman spectrum of chlorite.
The intensity of the band at $199 \mathrm{~cm}^{-1}$ is sensitive to the crystal orientation with respect to the polarization direction of the incident beam. The map in Fig. 5 shows the plot of the $199 \mathrm{~cm}^{-1}$ band intensity, measured after the normalization of the spectra, reproducing the textural placing of lamellae. Of course, in polished samples, it is easier to have textural information from optical or electron microscopy, but Raman maps could be obtained even on untreated archaeological samples, even in the presence of alterations.

Raman spectra obtained with the $632.8 \mathrm{~nm}$ excitation on talc and chlorite (and, sometimes, forsterite) crystals often show the typical photo-luminescence of $\mathrm{Cr}^{3+}$ ions at 680-682 $\mathrm{nm} .^{[17]}$

In many fragments, some carbonates were identified by Raman spectroscopy (Fig. 6): calcium carbonate $\left(\mathrm{CaCO}_{3}\right)$ in both calcite (more often) and aragonite polymorphs, magnesium carbonate $\left(\mathrm{MgCO}_{3}\right)$ magnesite and the mixed calcium-magnesium carbonate dolomite. ${ }^{[18]}$ Calcite and aragonite are easily distinguished by Raman spectroscopy thanks to the split and red-shift in aragonite of the $E_{g}$ mode at $702-706 \mathrm{~cm}^{-1}$ and, with larger evidence, by the $208 \mathrm{~cm}^{-1}$ and $283 \mathrm{~cm}^{-1}$ low-wavenumber bands. ${ }^{[19]}$

Table 2. Wavenumbers in $\mathrm{cm}^{-1}$ of the Raman bands observed with the micro-Raman apparatus in the mineral species identified in this work. vs $=$ very strong, $\mathrm{s}=$ strong, $\mathrm{m}=$ medium, $\mathrm{w}=$ weak

\begin{tabular}{|c|c|c|}
\hline Mineral & Formula & Observed Raman bands \\
\hline Talc & $\mathrm{Mg}_{3}\left(\mathrm{Si}_{4} \mathrm{O}_{10}\right) \mathrm{OH}_{2}$ & 195 s, 363 m, 676 s,1052 w, 3675 m \\
\hline Chlorite & $(\mathrm{Mg}, \mathrm{Fe})_{5} \mathrm{Al}\left(\mathrm{AlSi}_{3} \mathrm{O}_{10}\right)(\mathrm{OH})_{8}$ & 199 vs, 354 w, 547 m, 679 s, 3610 m, 3683 m \\
\hline Magnesite & $\mathrm{MgCO}_{3}$ & $211 \mathrm{~m}, 326 \mathrm{~s}, 738 \mathrm{w}, 1095$ vs \\
\hline Dolomite & $\mathrm{CaMg}\left(\mathrm{CO}_{3}\right)_{2}$ & 175 s, 298 s, 724 w, 1097 vs \\
\hline Calcite & $\mathrm{CaCO}_{3}$ & $155 \mathrm{~m}, 284 \mathrm{~m}, 711 \mathrm{w}, 1087$ vs \\
\hline Aragonite & $\mathrm{CaCO}_{3}$ & 153 m, 207 m, 701-705 w, 1086 vs \\
\hline Magnetite & $\mathrm{Fe}_{3} \mathrm{O}_{4}$ & $667 \mathrm{~s}$ \\
\hline Hematite & $\mathrm{Fe}_{2} \mathrm{O}_{3}$ & 225 s, 245 w, 292 s, 410 m, 612 w \\
\hline Forsterite & $\mathrm{Mg}_{2} \mathrm{SiO}_{4}$ & 227 w, 328 w,544 w, 592 w, 823 vs, 852 vs, 919 m, 962 w \\
\hline Pyrite & $\mathrm{FeS}_{2}$ & $340 \mathrm{~s}, 375 \mathrm{~s}$ \\
\hline Goethite & $\mathrm{FeOOH}$ & $298 \mathrm{~m}, 390 \mathrm{~s}$ \\
\hline Chrysotile & $\mathrm{Mg}_{6}\left[(\mathrm{OH})_{8} \mid \mathrm{Si}_{4} \mathrm{O}_{10}\right]$ & $231 \mathrm{w}, 387 \mathrm{~s}, 690 \mathrm{~m}$ \\
\hline Ilmenite & $\mathrm{FeTiO}_{3}$ & $232 \mathrm{w}, 371 \mathrm{~m}, 680 \mathrm{~s}$ \\
\hline
\end{tabular}



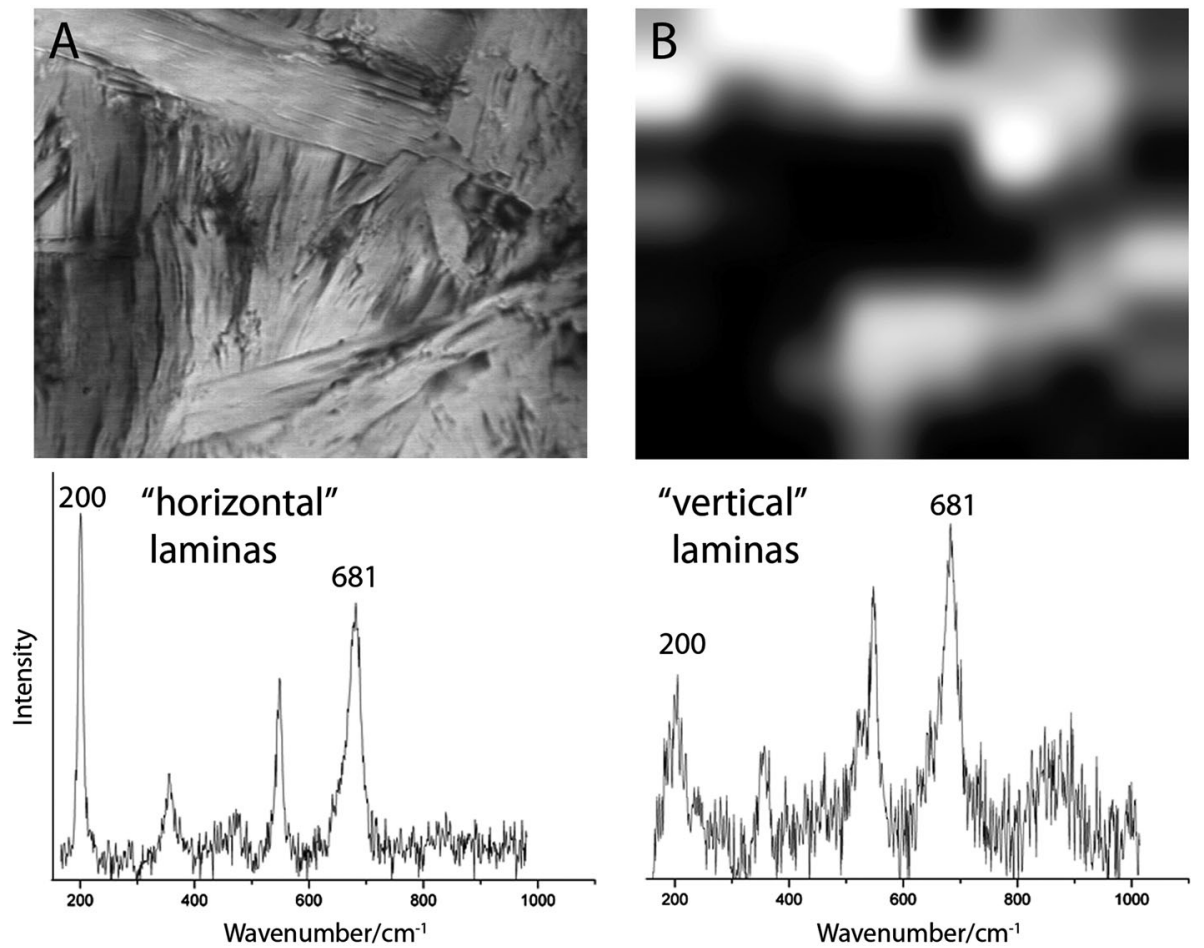

Figure 5. Raman micro-map of the orientation of the chlorite laminas in an archaeological sample. A) microscope image obtained with the 50x objective. B) Grey-scale map of the ratio between the areas of the bands at 681 and $200 \mathrm{~cm}^{-1}$. White = nearly horizontal laminas (laser polarization parallel to C axis). Black = nearly vertical laminas.

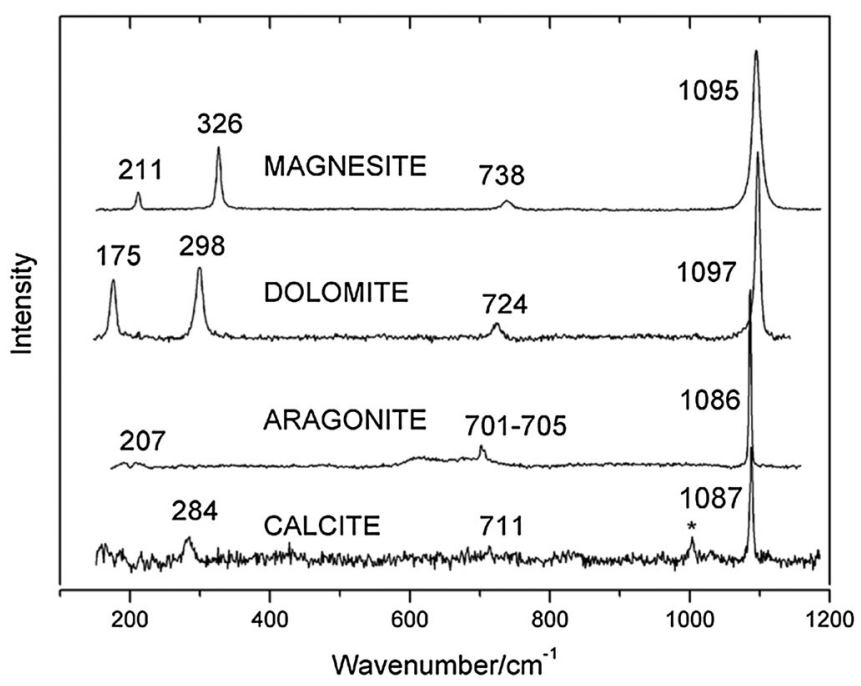

Figure 6. Micro-Raman spectra of the different carbonates found in the archaeological samples. ${ }^{*}=$ gypsum.

A member of the olivine series - $(\mathrm{Mg}, \mathrm{Fe})_{2} \mathrm{SiO}_{4}$ - was identified by Raman spectroscopy in some of the samples, thanks to the strong doublet between 800 and $900 \mathrm{~cm}^{-1}$ (Fig. 7): from the position of the bands, it is possible to estimate the content of magnesium/iron, useful to distinguish between fayalite- or forsterite-rich members. ${ }^{[20]}$ In our samples, the two main bands are at $823-855 \mathrm{~cm}^{-1}$, corresponding to a forsterite-rich member (90\%Fo-10\%Fa).

Raman spectroscopy has also identified secondary ironcontaining oxides goethite $(\alpha-\mathrm{FeOOH})$, hematite $\left(\alpha-\mathrm{Fe}_{2} \mathrm{O}_{3}\right)$, magnetite $\left(\mathrm{Fe}_{3} \mathrm{O}_{4}\right)$, ilmenite $\left(\mathrm{FeTiO}_{3}\right)^{[21,22]}$ and iron sulfide pyrite

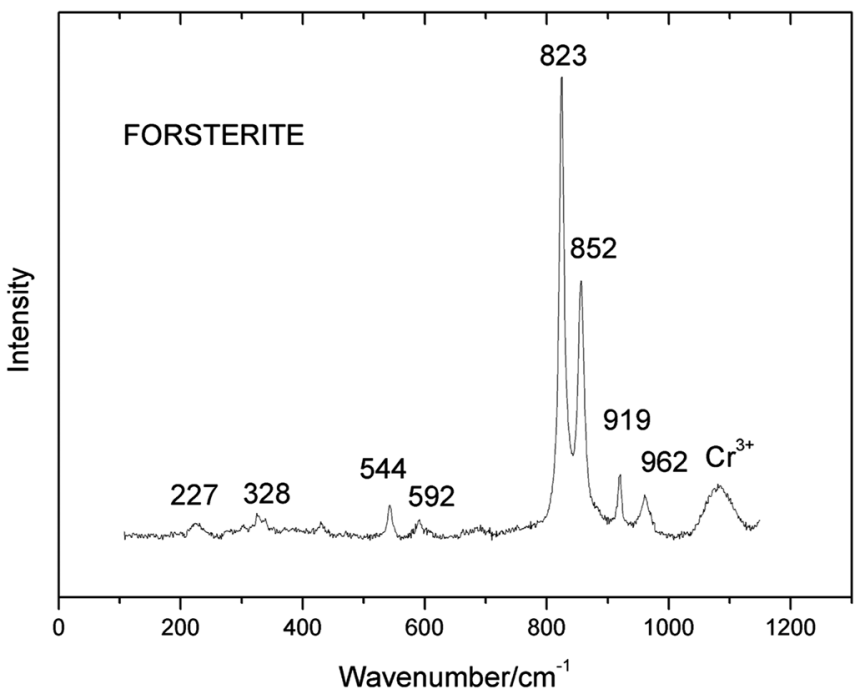

Figure 7. Micro-Raman spectra of forsterite measured on the archaeological samples. A photoluminescence emission of $\mathrm{Cr}^{3+}$ ions is visible.

$\left(\mathrm{FeS}_{2}\right)$. The various phases detected on the different samples are summarized in Table 3.

\section{XRD}

As we can see, in almost all samples, talc is present as the most abundant mineral (Fig. 8); the only exception is sample \#10, where it is still detected but the principal mineral is the most common member of the chlorite group: clinochlore $\left(\mathrm{Mg}, \mathrm{Fe}^{2+}\right)$ ${ }_{5} \mathrm{Al}\left(\mathrm{Si}_{3} \mathrm{Al}\right) \mathrm{O}_{10}(\mathrm{OH})_{8}$. 
Table 3. Mineral species identified in the fragments by Raman, XRD and SEM-EDX

\begin{tabular}{|c|c|c|c|c|}
\hline Sample N. & $\begin{array}{l}\text { Catalog reference } \\
\text { and stratigraphic unit }\end{array}$ & Raman & XRD & SEM-EDX \\
\hline$\# 1$ & S.A.B. 96 US $805-806$ & $\begin{array}{l}\text { Talc, Chlorite, Magnesite, } \\
\text { Magnetite }\end{array}$ & $\begin{array}{l}\text { Talc, Cr-Clinochlore, } \\
\text { Magnesite, Dolomite }\end{array}$ & Talc, Chlorite, Magnesite \\
\hline$\# 2$ & S.A.B.97 US 931 & Talc, Magnesite, Magnetite & $\begin{array}{l}\text { Talc, Cr-Clinochlore, } \\
\text { Magnesite, Magnetite }\end{array}$ & Talc, Chlorite, Magnesite \\
\hline \#3 & S.A.B. 96 US 793 & Talc, Chlorite, Magnesite & $\begin{array}{l}\text { Talc, Cr-Clinochlore, } \\
\text { Magnesite, K-mica }\end{array}$ & Talc, Chlorite, Magnesite \\
\hline$\# 4$ & S.A.B. 95 Splat & $\begin{array}{l}\text { Talc, Chlorite, Magnesite, } \\
\text { Dolomite, Magnetite }\end{array}$ & $\begin{array}{l}\text { Talc, Cr-Clinochlore, } \\
\text { Dolomite, Plagioclasio, } \\
\text { Magnetite, K-Mica, Cristobalite }\end{array}$ & $\begin{array}{l}\text { Talc, Chlorite, Magnesite, } \\
\text { Dolomite }\end{array}$ \\
\hline$\# 5$ & S.A.B. 97 US 1203 & $\begin{array}{l}\text { Talc, Magnesite, Goethite, } \\
\text { Forsterite, Hematite }\end{array}$ & $\begin{array}{l}\text { Talc, Cr-Clinochlore, } \\
\text { Magnesite, Dolomite }\end{array}$ & Talc, Chlorite, Magnesite \\
\hline \#6 & S.A.B. 95 US 548 & $\begin{array}{l}\text { Talc, Chlorite, Magnetite, } \\
\text { Pirite, Piroxene }\end{array}$ & Talc, Diopside & Talc \\
\hline \#7 & S.A.B. 96 US 643 & $\begin{array}{l}\text { Talc, Calcite, Hematite, } \\
\text { Magnetite, Forsterite }\end{array}$ & Talc, Cr-Clinochlore, Magnetite & Talc, Chlorite \\
\hline \#8 & S.A.B. 97 US 1124 & $\begin{array}{l}\text { Talc, Chlorite, Calcite, } \\
\text { Dolomite, Goethite }\end{array}$ & $\begin{array}{l}\text { Talc, Cr-Clinochlore, Magnesite, } \\
\text { Dolomite, K-Mica }\end{array}$ & $\begin{array}{l}\text { Talc, Chlorite, Magnesite, } \\
\text { Dolomite }\end{array}$ \\
\hline$\# 9$ & S.A.B. 86 US 4 & $\begin{array}{c}\text { Talc, Calcite, Aragonite, Hematite, } \\
\text { Magnetite, Forsterite, Piroxene }\end{array}$ & $\begin{array}{l}\text { Talc, Magnesite, Aragonite, } \\
\text { Forsterite, Enstatite }\end{array}$ & $\begin{array}{l}\text { Talc, Chlorite, Calcite } \\
\text { (or Aragonite) }\end{array}$ \\
\hline$\# 10$ & S.A.B. 96 US 51 66N & $\begin{array}{l}\text { Talc, Chlorite, Magnesite, } \\
\text { Dolomite, Ilmenite }\end{array}$ & $\begin{array}{l}\text { Talc, Cr-Clinochlore, Magnesite, } \\
\text { Dolomite, Ilmenite }\end{array}$ & $\begin{array}{l}\text { Talc, Chlorite, Magnesite, } \\
\text { Dolomite, Ilmenite }\end{array}$ \\
\hline
\end{tabular}

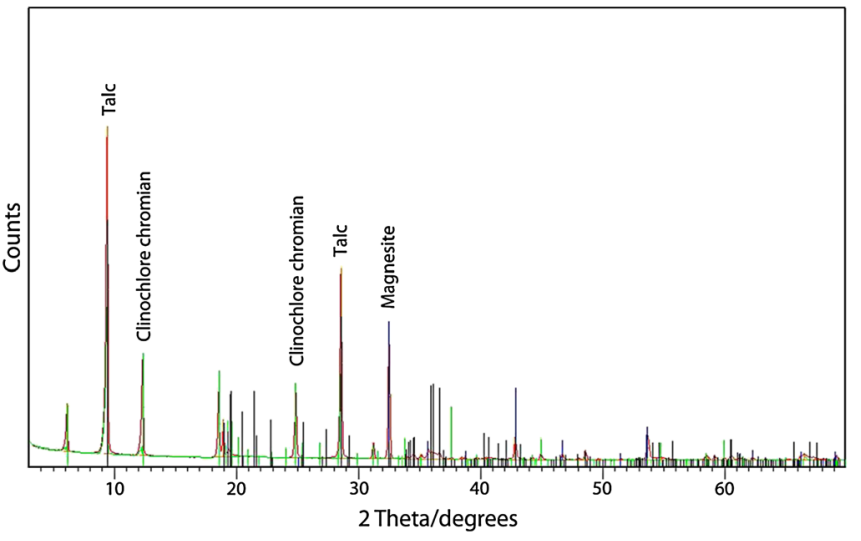

Figure 8. XRD pattern of the sample SAB96 793 showing the presence of talc, clinochlore and magnesite.

Clinochlore is present in considerable amount in eight samples (absent in \#9 and \#6); in particular, the XRD results well agree with the pattern of the chromian variety of clinochlore. Between carbonates, magnesite is the most frequently detected phase (seven samples), dolomite is present in half of the samples, while aragonite is detected only in sample \#9. The presence of aragonite is hard to explain: it could be of secondary origin. Less abundant minerals as forsterite and enstatite are rarely detected while in sample \#4 different accessory phases are found: plagioclase, magnetite and cristobalite.

\section{SEM-EDX}

The semi-quantitative elemental analysis confirms that all samples contain talc. In all samples, except \#6, a mineral belonging to the chlorite group is found. Based on the ratio of $\mathrm{Fe}, \mathrm{Fe} / \mathrm{Mg}$ and $\mathrm{Si}$, it is possible to classify the type of chlorite present in the samples ${ }^{[23]}$ (Fig. 9). Most of the measuring points (belonging to all the samples) fall in the clinochlore or pennine regions. Only few points of two samples (\#4 and \#10) are in the talc-chlorite zone.

We also found different types of carbonates, identified as magnesite, calcite, aragonite and dolomite.

\section{Portable Raman spectroscopy}

In order to evaluate the provenance of an unknown rock fragment, we performed some in situ Raman measurements on the lithotype exploited in the inspected quarry of Piuro, near Chiavenna; hence, it was possible to analyze fresh cuts of the rocks. The use of two different excitation lines allowed the

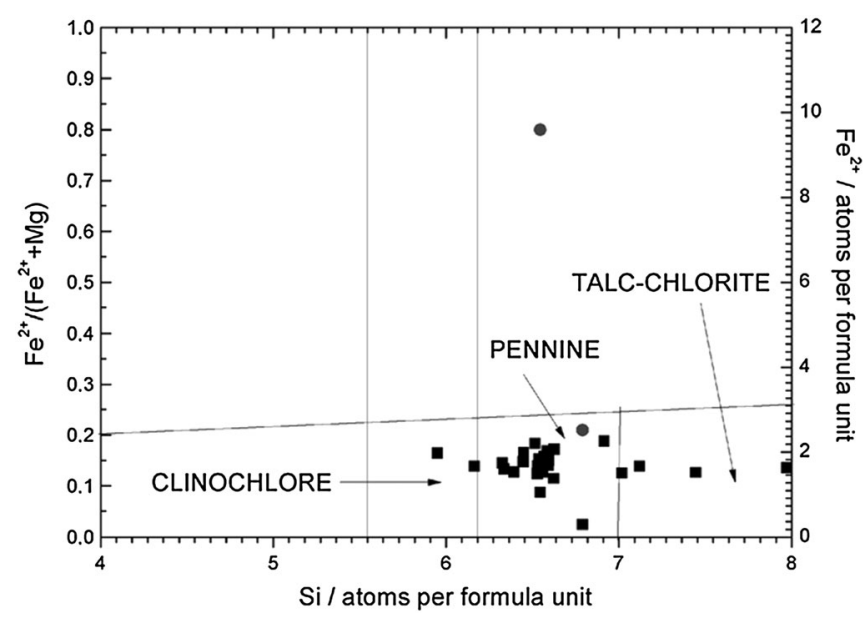

Figure 9. Composition of the chlorite crystals, in terms of $\mathrm{Fe}^{2+}$ and $\mathrm{Si}$ ions, obtained on archaeological samples by SEM-EDX measurements. 


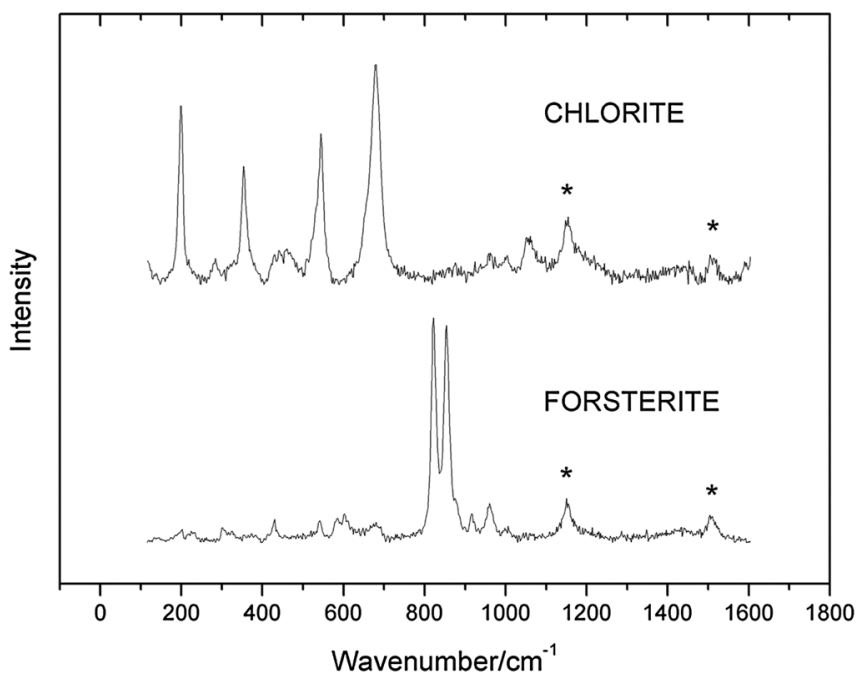

Figure 10. Raman spectra of chlorite and forsterite measured in situ with the portable spectrometer, obtained with the green excitation at $532 \mathrm{~nm}$. The bands of biogenic carotenoids present on the rocks surfaces are clearly visible $\left(^{*}\right)$.

minimization of the fluorescence, giving good results on all analyzed rocks. Talc, chlorite and olivine were clearly detected in all the samples. In particular, the spectral resolution of the portable spectrometer is good enough to discriminate between talc and chlorite; their quantification is, however, difficult due to the partial overlap of their Raman features. The Raman doublet of olivine at $823-855 \mathrm{~cm}^{-1}$ is very strong and in many cases (especially with the $532 \mathrm{~nm}$ excitation) dominates the spectra (Fig. 10). The position of the two main bands of olivine is also measured on the archaeological artifacts $\left(823-855 \mathrm{~cm}^{-1}\right)$, indicating the same chemical composition (90\% forsterite - $10 \%$ fayalite). ${ }^{[20]}$ Even in the presence of high humidity (the quarry is located very near to a waterfall), the spectra obtained on the rock surfaces show no environmental interferences, except for the strong bands at 1150 and $1505 \mathrm{~cm}^{-1}$ due to biogenic carotenoids, clearly visible on the spectra recorded with the $532 \mathrm{~nm}$ excitation line, thanks to the resonance effect ${ }^{[24]}$ (Fig. 10).

\section{Discussion}

In all the samples, talc is present in a significant quantity except for samples \#10 and \#8 where talc concentration is low. In some cases, (for example \#10) the principal mineral belongs to the chlorite group. XRD and chemical analysis have identified clinochlore as the main chlorite in the samples. Carbonates are present in all samples except \#6. SEM-EDX measurements essentially confirm the Raman and XRD results.

From the mineralogical composition and petrographic fabric, the pietra ollare composing our fragments can be characterized as chlorite and magnesite-bearing talc-schist. Goethite is found as a secondary mineral; this mineral is not stable at the talc-schist formation conditions, but its presence is explainable as secondary alteration of the artifacts during their burial period.

Talc schists derive from the metamorphism of ultramafic mantle rocks (peridotites) during emplacements in the oceanic crust. They are generally associated with ophiolite outcrops, i.e. old portions of oceanic crust formed by a petrographic succession series where peridotites are at the base and basalts at the top. This origin is confirmed by the presence of forsterite and traces of chromium in talc and chlorite, as evidenced by the typical chromium photo-luminescence visible in the microRaman spectra.

More generally speaking, 11 different lithotypes have been assigned by Mannoni et al. ${ }^{[2]}$ to the various alpine outcrops of metamorphic rocks known as pietra ollare. Based on petrography, mineralogic and chemical peculiarities, the talc-schists studied could be assigned to group D proposed by Mannoni and coworkers ${ }^{[2]}$ : 'fine grained magnesite talc-schists' coming from Valchiavenna. In particular, we can assign our fragments to the subgroup (b): chlorite and carbonate containing talc-schist. These fine grain talc-carbonatic rocks contain very high amounts of talc and carbonates (basically magnesite) as principal mineralogical components, even if chlorite, magnetite and pyrite are also present. Our results, compared with current literature data, ${ }^{[2,5,6]}$ clearly indicate Valchiavenna as the source of the pietra ollare found in the archaeological site of Crocetta di Sant'Agata Bolognese.

In order to try to establish a completely non-destructive way to study the provenance of lapidary artifacts, we tested the possibility to perform in situ analysis. The results obtained with the mobile equipment are in good agreement with those obtained with laboratory instruments, although the degree of detail might be lower.

As for other portable Raman systems, ${ }^{[13,14,25,26]}$ one of the main differences respect to a micro-Raman apparatus is the lower mechanical stability of the acquisition setup. This implies the use of objectives with lower magnification and lower numerical aperture, resulting in a lower spatial resolution and a lower sensitivity. For that reason, with the laboratory spectrometer, it was possible to detect also minor phases, such as iron oxides, pyrite and pyroxene, not detected in situ. In addition, in laboratory, it was also possible to study the crystal orientation. The mobile instrumentation allowed the detection of the main components, often together in the same spot, due to the lower spatial resolution.

Further comparing our mobile and laboratory Raman equipment, the short focal length of the mobile spectrometer gives a lower spectral resolution. However, for this particular application, it was enough to discriminate all the phases, and the overall quality of the obtained spectra, for the main phases, is comparable, as visible from the chlorite spectra in Figs. 4 and 10. Compatible results are obtained, not only in terms of the main components (talc, chlorite, forsterite) but also in terms of composition of the olivine (Fe content) estimated from the Raman spectra. With respect to smaller and more light-weight handheld Raman spectrometers used for the field analysis of minerals, ${ }^{[24,25]}$ the instrument used in this work has higher spectral resolution, a filter cutoff at lower wavenumber, allowing the full detection of bands at less than $200 \mathrm{~cm}^{-1}$ (see chlorite bands in Fig. 10) and has a double excitation line. The last point is very useful to optimize the detection of different phases: as an example, the 532 $\mathrm{nm}$ line enhanced the signal of forsterite, while the 785 line was used to minimize interferences from organic materials to detect minerals with weak signal.

\section{Conclusions}

The analyses (Raman, SEM-EDX, XRD, petrography) made on the samples allowed the identification of their mineralogical 
composition and indicate that the samples here investigated could be mostly considered as fine-grained magnesite talcschists, belonging to group D of the classification proposed by Mannoni et al., ${ }^{[2]}$ although some differences are present between the various fragments. The alpine areas of origin of this lithotype are Valtellina, Valchiavenna and Val Bregaglia. The particular subtype of our samples, corresponding to the 'chlorite and carbonate containing talc-schist' subgroup, ${ }^{[2,5,6]}$ allows identifying Valchiavenna as the provenance of the raw material. Archaeological and archaeometric literature ${ }^{[2,5-8]}$ is in agreement about the important role of Valchiavenna in the commercial trade and in the daily consumption of towns, castra and settlements in North Italy. As a consequence, the export of alpine graft artifact, as pietra ollare pots, also in the Po Plain and further away, largely increased. ${ }^{[5,6]}$ According to the analysis of Valchiavenna's quarry samples and in agreement with the historical importance of this zone as commercial crossway, we could hypothesize that the provenance of Sant'Agata Bolognese's samples is Valchiavenna.

Although other types of analysis (i.e. trace elements or isotope analysis) might provide a higher level of detail and a better definition of the provenance, Raman spectroscopy has proven to be a good tool for the characterization of pietra ollare artifacts that could be performed in situ. XRD and SEM-EDX essentially confirm the results of Raman spectroscopy, even if they add some details (especially on chlorite minerals) and give a better quantification of the main phases. In particular, petrographic information obtained with the thin-section study allows a more fine subdivision of our samples in three types: carbonate (magnesite)-bearing talc-schists, pure talc-schists, talc-carbonate (magnesite and dolomite)-bearing chlorite-schists, all of them compatible with the proposed provenance. The identification of carbonates is very important in this classification and was greatly eased by Raman spectroscopy.

The combination of laboratory micro-Raman measurements on archaeological samples and in situ measurements with mobile spectrometers can be a good approach to start a campaign of provenance analysis on lapidary archaeological materials of unknown origin in a completely non-destructive way, especially in the absence of reference samples with established provenance.

\section{Acknowledgements}

The authors are very grateful to Alvaro Caligari for sharing his knowledge on the mountains and geology of Valchiavenna. PV wishes to acknowledge the FP7-project MEMORI - 'Measurement, Effect Assessment and Mitigation of Pollutant Impact on Movable Cultural Assets. Innovative Research for Market Transfer' (http:// www.memori-project.eu/memori.html). The authors are also grateful to Prof. A. Renzulli and Dr. P. Santi of the 'Carlo Bo' University of Urbino for made available some quarry samples used as Raman standards.

\section{References}

[1] F. Antonelli, P. Santi, A. Renzulli, A. Bonazza, Petrographic features and thermal behaviour of the historically known pietra ollare from the Italian Central Alps (Valchiavenna and Valmalenco), in Geomaterials in Cultural Heritage (Ed.: M. Maggetti, B. Messiga), Geological Society of London, Special Pubblication 257, London, 2006, 229-239.

[2] T. Mannoni, H. R. Pfeifer, V. Serneels, La pietra ollare dalla preistoria all'età moderna" conference proceedings, Como, October 16-17, 1982, Edizioni New Press, Como, Italy, 1987, 7-45.

[3] S. Gelichi, M. Librenti, Campagne Medioevali. Strutture materiali, economia e società nell'insediamento rurale dell'Italia Settentrionale (VIII-X secolo). Conference proceedings, Nonantola (Mo) and San Giovanni in Persiceto (Bo), 14-15 march 2003, SAP Società archeologica s.r.l., Mantova (Italy), 2005, 101-117.

[4] F. Antonelli, L. Lazzarini, Archaeometry 2012, 54, 1-17.

[5] P. Santi, F. Antonelli, A. Renzulli, Archaeometry 2005, 47, 253-264.

[6] P. Santi, F. Antonelli, A. Renzulli, A. Alberti, J. Archaeol. Sci. 2009, 36, 2493-2501.

[7] T. Mannoni, B. Messiga, $6^{\circ}$ Congresso Internazionale di studi sull'Alto Medioevo. Conference proceedings, 1978, Milano (Italy), 1980, 501-522.

[8] C. Malaguti, A. Zane, Archeologia Medievale 1999, 26, 463-479.

[9] Ph. Colomban, J. Raman Spectrosc. 2012, 43, 1529-1535.

[10] J. Jehlička, P. Vítek, H. G. M. Edwards, M. Heagraves, T. Čapoun, Spectrochim. Acta, Part A 2009, 73, 410-419.

[11] P. Vandenabeele, K. Castro, M. Hargreaves, L. Moens, J. M. Madariaga, H. G. M. Edwards, Anal. Chim. Acta 2007, 588, 108-116.

[12] D. Bersani, P. P. Lottici, F. Vignali, G. Zanichelli, J. Raman Spectrosc. 2006, 37, 1012-1018.

[13] P. Vandenabeele, H. G. M. Edwards, J. Jehlička, Chem. Soc. Rev. (submitted).

[14] D. Lauwers, A. Garcia Hutado, V. Tanevska, L. Moens, D. Bersani, P. Vandenabeele, Spectrochim. Acta, Part A 2013. DOI: 10.1016/j. saa.2013.08.088

[15] A. Wang, J. Freeman, K. E. Kuebler, Raman spectroscopic characterization of phyllosilicates (2002). In Lunar and Planetary Science XXXIII 2002, abstract no.1374, proceedings of 33rd Annual Lunar and Planetary Science Conference, Houston, Texas, March 11-15, 2002.

[16] D. Lau, C. Villis, S. Sfurman, M. Livett, Anal. Chim. Acta 2008, 610, 15.

[17] M. Gaft, R. Reisfeld, G. Panczer (Eds.), Modern Luminescence Spectroscopy of Minerals and Materials, Springer, Berlin Heidelberg New York, 2005.

[18] R. G. Herman, C. E. Bogdan, A. J. Sommer, D. R. Simpson, Appl. Spectrosc. 1987, 41, 437-440.

[19] J. E. Parker, S. P. Thompson, A. R. Lennie, J. Potter, C. C. Tang, Cryst. Eng. Comm. 2010, 12, 1590-1599.

[20] K. E. Kuebler, B. L. Jolliff, A. Wang, L. A. Haskin, Geochim. Cosmochim. Acta 2006, 70, 6201-6222.

[21] D. Bersani, P. P. Lottici, A. Montenero, J. Raman Spectrosc. 1999, 30, 355-360.

[22] D. Bersani, P. P. Lottici, A. Montenero, J. Mater. Sci. 2000, 35, 1-5.

[23] W. A. Deer, R. A. Howie, Y. Zussman, Rock-forming minerals. Layered silicates excluding micas and clay minerals, vol. 3B, (2nd edn), The Geological Society, London, 2009.

[24] L. Bergamonti, D. Bersani, D. Csermely, P. P. Lottici, Spectrosc. Lett. 2011, 44, 453-458.

[25] J. Jehlička, A. Culka, P. Vandenabeele, H. G. M. Edwards, Spectrochim. Acta, Part A 2011, 80, 36-40.

[26] P. Vítek, J. Jehlička, H. G. M. Edwards, Appl. Spectrosc. 2013, 67, 703-812. 